\title{
"In vivo" toxicity of a truncated version of the Drosophila Rst-IrreC protein is dependent on the presence of a glutamine-rich region in its intracellular domain
}

\author{
RICARDO C. MACHADO ${ }^{1,2}$, RODRIGO N.R. PEREIRA ${ }^{1 *}$, MARA S.A. COSTA ${ }^{1}$ \\ and RICARDO GUELERMAN P. RAMOS ${ }^{1}$ \\ ${ }^{1}$ Departamento de Biologia Celular e Molecular e Bioagentes Patogênicos \\ Faculdade de Medicina de Ribeirão Preto, Universidade de São Paulo, 14040-900 Ribeirão Preto, SP. \\ ${ }^{2}$ Instituto de Biofísica Carlos Chagas Filho, Universidade Federal do Rio de Janeiro \\ Manuscript received on November 22, 2001; accepted for publication on February 26, 2002; \\ presented by RAFAEL LINDEN
}

\begin{abstract}
The roughest-irregular chiasm C (rst-irreC) gene of Drosophila melanogaster encodes a transmembrane glycoprotein containing five immunoglobulin-like domains in its extracellular portion and an intracytoplasmic tail rich in serine and threonine as well some conserved motifs suggesting signal transduction activity. In the compound eye, loss-of-function rst-irreC mutants lack the characteristic wave of programmed cell death happening in early pupa and which is essential for the elimination of the surplus interommatidial cells. Here we report an investigation on the role played by the Rst-irreC molecule in triggering programmed cell death. "In vivo" transient expression assays showed that deletion of the last 80 amino acids of the carboxyl terminus produces a form of the protein that is highly toxic to larvae. This toxicity is suppressed if an additional 47 amino acid long, glutamine-rich region ("opa-like domain"), is also removed from the protein. The results suggest the possibility that the opa-like domain and the carboxyl terminus act in concert to modulate rstirre C function in apoptosis, and we discuss this implication in the context of the general mechanisms causing glutamine-rich neurodegenerative diseases in humans.
\end{abstract}

Key words: Drosophila, rst-irreC, glutamine-rich repeats, cell death.

\section{INTRODUCTION}

One of the key problems faced by multicellular organisms during development is the control of cell number. Unchecked proliferation may cause hyperplasia and interfere with growing of adjacent tissue while excess or inappropriate cell death can result in an insufficient number of cells to form a tissue, or in its degeneration. A delicate balance between cell

Correspondence to: Ricardo G.P. Ramos

E-mail: rgpramos@fmrp.usp.br

*Present address: Departamento de Fisiologia, Faculdade de Medicina de Ribeirão Preto - Universidade de São Paulo proliferation and the elimination of surplus or defective cells must therefore be maintained throughout morphogenesis so that the correct structural organization and function of a given organ or tissue can be achieved. Although a lot of attention has been devoted to the study of the molecular and cellular basis of the mechanisms controlling cell division, very little was known, until recently, about how programmed cell death is regulated during tissue growth and differentiation. In the last few years however, work carried out in several model organisms, especially the nematode Caenorhabditis ele- 
gans and the dipteran Drosophila melanogaster, as well as in vertebrate systems, resulted in the unraveling of a basic molecular mechanism by which programmed cell death is triggered during development. This apoptotic mechanism, highly conserved phylogenetically from worms to mammals, is dependent on the activation, inside the cell, of a cascade of cysteinyl aspartate-specific proteinases - caspases in response to a variety of death signals, leading to characteristic morphological and molecular changes including cell shrinkage, membrane blebbing, chromatin condensation, and extensive DNA fragmentation, which culminate in the complete removal of the dying cell without lysis, its contents being engulfed by phagocytes or neighboring cells. (See Ashkenazi and Dixit 1998, Thornberry and Lazebnick 1998, Green and Reed 1998, Raff 1998 for recent reviews).

The final steps of compound eye development in D. melanogaster offer a particularly instructive example of the importance of programmed cell death in establishing the correct structural patterning of a functional structure. Ommatidial patterning in this insect occurs through a series of sequential decisions that are critically dependent on local cell interactions, and culminates, around $30 \%$ of pupal development, in a wave of programmed cell death by which the remaining unpatterned interommatidial cells are removed and the highly organized, crystalline-like structure of the wild type compound eye emerges. This last step is dependent on the correct function of at least two genes: echinus (ec) and roughest-irregular chiasm C (rst-irreC). Lossof-function mutations in any of these loci lead to an absence of programmed cell death in the compound eye during pupal stages (Wolff and Ready 1991, 1993). ec has not yet been fully characterized at the molecular level but rst-irre $C$ encodes a 764 amino acid long transmembrane glycoprotein displaying five immunoglobulin-like domains in its extracellular portion and a cytoplasmic tail rich in serine and threonine residues (Ramos et al. 1993). Several additional features can be found in the intracellular part of the molecule, including a putative consensus sequence recognized by PDZ domain proteins (Ponting et al. 1997) at its carboxyl terminus as well as 24 amino acid long stretch composed predominantly of glutamines, ("opa-like"' sequence: Wharton et al. 1985) between residues 637 and 660. This latter feature is of special interest, since expanded glutamine repeats were recently shown to be present in a number of important neurodegenerative disorders in humans including Huntington's disease (Gusella et al. 1996), spinobulbar muscular atrophy, (La Spada et al. 1991) dentatorubralpallidoluysian atrophy (Koide et al. 1994, Nagafuchi et al. 1994) and spinocerebelar ataxias such as the Machado-Joseph's disease (Kawagushi et al. 1994). Besides its role in ommatidial patterning, wild type rst-irreC function is also required for embryonic myogenesis, (Strünkelnberg et al. 2001) as well as for axonal pathfinding in the optic lobe and bristle differentiation in the head (Boschert et al. 1990).

Molecular analysis of mutant alleles of rst-irreC showed that the integrity of the intracellular domain is critical for its role in ommatidial assembly: mutant rst-irreC flies producing a RstIrreC protein with a truncated intracellular domain, but having normal extracellular and transmembrane portions, show an eye "roughening" phenotype (caused by the lack of cell death and the presence of surplus cells, that disrupt the highly regular ommatidial stucture) as severe as those observed in null alleles (Wolff and Ready 1991, Ramos et al. 1993).

As a first step to gain a better understanding of the functional role played by the different subdomains that comprise the intracytoplasmic portion of the Rst-IrreC protein we generated truncated versions of the rst-irre C cDNA, coding for polypeptides completely or partially lacking the intracellular region and examined the phenotypic effects of their transient expression after microinjection into wild type Drosophila embryos at preblastoderm stage. Here we report that injection of a construct encoding a protein lacking the last 80 amino acids of the carboxyl terminus of the wild type molecule leads to a dramatic decrease in post embryonic viability when compared both with controls injected only with the 
vector and with a construct encoding the complete wild type protein. Interestingly, injection of a construct without the opa-like, glutamine-rich region shows post-embryonic survival levels comparable to the controls. Based on these findings we suggest a model in which the opa-like domain and the carboxyl terminus could act in concert to modulate an apoptosis-inducing function for Rst-IrreC.

\section{MATERIALS AND METHODS}

\section{Drosophila Stocks and Genetic}

Manipulations

Unless otherwise stated fly stocks were kept at $25^{\circ} \mathrm{C}$ in standard fly food. Grapejuice egg-collecting medium was prepared as described in Ashburner (1989). A complete description of the mutants mentioned in the text can be found in Boschert et al. (1990) and Lindsley and Zimm (1992).

\section{Nucleic Acid Manipulations and Constructs}

All DNA manipulations were performed using standard techniques (Sambrook et al. 1989). The pCa18Z construct was made in two steps: first the initial 1.19kb DNA fragment from rst-irreC cDNAHB3 (Ramos et al. 1993), was subcloned in the correct orientation into the EcoRI site of P-element transformation vector pCaSpeR-hs (Thummel and Pirrota 1991) generating intermediate construct pCa18. This plasmid was then restriction digested with enzymes KpnI and BgIII and ligated to a $1.18 \mathrm{~kb}$ KpnI-BamHI fragment from cDNA-HB3. The resulting final construct encodes a 688 amino acid polypeptide composed of residues 1-684 from the wild type Rst-IrreC protein plus 5 residues, AAAV, added to its carboxyl terminus.

Construct pCa18Z $\Delta 1$ was a derivative of pCa18Z in which $140 \mathrm{bp}$ were additionally removed from its insert by treating it with exonuclease III, followed by digestion with S1 nuclease (Machado 1997). The resulting construct encodes a 639 amino acid polypeptide composed of amino acids 1-637 from wild type Rst-IrreC protein plus two prolines added to its carboxyl terminus.
Plasmid pKB256-HB3 is a P-element transformation vector carrying an insert containing the complete open reading frame from rst-irreC cDNA HB3 (Schneider et al. 1995).

\section{EMbryo MicroinJeCtion AND \\ Post-InJeCtion CARE}

Microinjection of preblastoderm $y w^{1118}$ embryos was performed essentially as described in Spradling (1986) and Ramos (1988). Females were allowed to lay eggs for one hour on grapejuice agar plates. Eggs were dechorionated with a $50 \%$ solution of commercial bleach, and aligned manually on a strip of double stick tape (Scotch ${ }^{\circledR}$ ) mounted on a microscope slide, briefly desiccated in dryerite ${ }^{\circledR}$, covered with halocarbon oil and injected at their posterior pole with a capillary needle attached to a Leica micromanipulator. Concentration of injected DNA was usually $0.5-0.8 \mathrm{mg} / \mathrm{ml}$. After injection, the double stick tape strips containing the eggs were carefully removed from the slides and transferred to grape juice plates. After incubation at $18^{\circ} \mathrm{C}$ for 36 hours, hatched larvae were individually picked, transferred to vials containing standard food and allowed to develop until adulthood at $25^{\circ} \mathrm{C}$. The number of pupae and, afterwards, the eclosed adults were counted, and compared with the total number of larvae initially put into each vial, in order to establish the post embryonic viability. In order to prevent overcrowding, not more than 30 injected larvae were usually put into each vial.

\section{RESULTS}

InJeCtion OF PCA18Z in PREBLASTODERM

Embryos Drastically Reduces their Viability

In designing a strategy for an "in vivo" functional dissection of the Rst-irreC protein we initially divided the intracellular portion of the molecule in two major structural domains, based primarily on their hydropathic properties, shown in Figure 1. Domain one spans a very hydrophilic region starting immediately after the transmembrane domain and comprising roughly residues 550 to 660 . It can, in turn, 
be further subdivided into a near transmembrane hydrophilic region (Domain Ia) and a glutamine-rich region (Domain $\mathrm{Ib}$ ). The second domain includes the remaining 104 amino acids of the carboxyl part of the molecule and alternates small hydrophobic and hydrophilic regions.

In an attempt to correlate these structural domains with specific functions of the rst-irreC gene we generated several constructs, deleting progressively larger portions of the cytoplasmic region of the protein, while respecting the approximate boundaries of the above mentioned intracellular subdomains. Here we report the results of "in vivo" transient expression assays using two of the constructs, pCa18Z and pCa18Z $\Delta 1$. Plasmid pCa18Z deletes most, but not all, of domain II (Fig. 1). Construct pCa18Z $\Delta 1$ completely removes domain II plus the glutamine-rich region of domain Ib. Both constructs were put under the control of the heat shock protein 70 promoter (Lis et al. 1983) by cloning them into the Drosophila transformation vector pCaSpER-Hs (Thummel and Pirrota 1991). DNA was injected in embryos prior to the cellularization stage as described in Methods. As controls we used pCaSpER-Hs DNA, as well as pKB256$\mathrm{HB} 3$, a construct containing the complete open reading frame of rst-irreC cDNA HB3 (Schneider et al. 1995). The percentages of injected embryos surviving up to adult stage were calculated for each construct and are shown in Figure 2. Individuals injected with pCa18Z showed a clear decrease in survival rate when compared with those injected with the vector alone, or with the construct carrying the complete rst-irre $C$ open reading frame. Injection of pCa18Z $\Delta 1$ on the other hand did not seem to affect survival beyond control levels, strongly suggesting that the 139bp sequence encoding a glutamine-rich region is responsible for the observed toxicity of pCa18Z construct.

\section{PCA18Z Affects OnLy Post Embryonic VIABILITY}

Having established that a truncated form of the RstirreC protein produced by plasmid $\mathrm{pCa} 18 \mathrm{Z}$ induces lethality when injected into early embryos we further investigated whether the actual death occurred during embryogenesis, at post embryonic stages or continuously throughout development. To this end embryos were injected with same plasmids as above and the percentage of hatched larvae determined for each construct. As shown in Figure 3, the viability of embryos injected with different constructs and with the vector pCaSpER are approximately the same. The low viability obtained with all plasmids is a consequence of the injection trauma rather than any non-specific toxic effect of the injected DNAs, since embryos injected only with injection buffer showed similarly low hatching levels (data not shown). Thus, only post embryonic viability seems to be affected by the injection of pCa18Z. This was confirmed by examining the percentage of hatched larva from the previous experiment that reached adulthood (Fig. 4). However, once only post embryonic survival rates were taken into account, a small, but consistent, lowering of viability could be observed in embryos injected both with KB256-HB3 and pCa18Z in comparison with those injected with the vector alone, suggesting that ectopic expression of the wild type IrreC-rst protein might have a slight toxic effect not associated to the glutamine-rich region.

\section{DISCUSSION}

Transient expression of genes microinjected in embryos before cellularization has been extensively documented and the fate of their DNA followed throughout embryonic and post embryonic stages (Steller and Pirrota 1984, 1985, Martin et al. 1986). Injected DNA can be found in the nuclei of most cells and tissues of the embryo, larvae and even adults. Developmental and tissue specificity of transcription tend to be at least partially retained, and are independent of actual integration in the genome. These characteristics make "in vivo" transient assays a convenient method to quickly assess viability, as well as the presence of dominant phenotypes, before attempting to generate germline transformed 


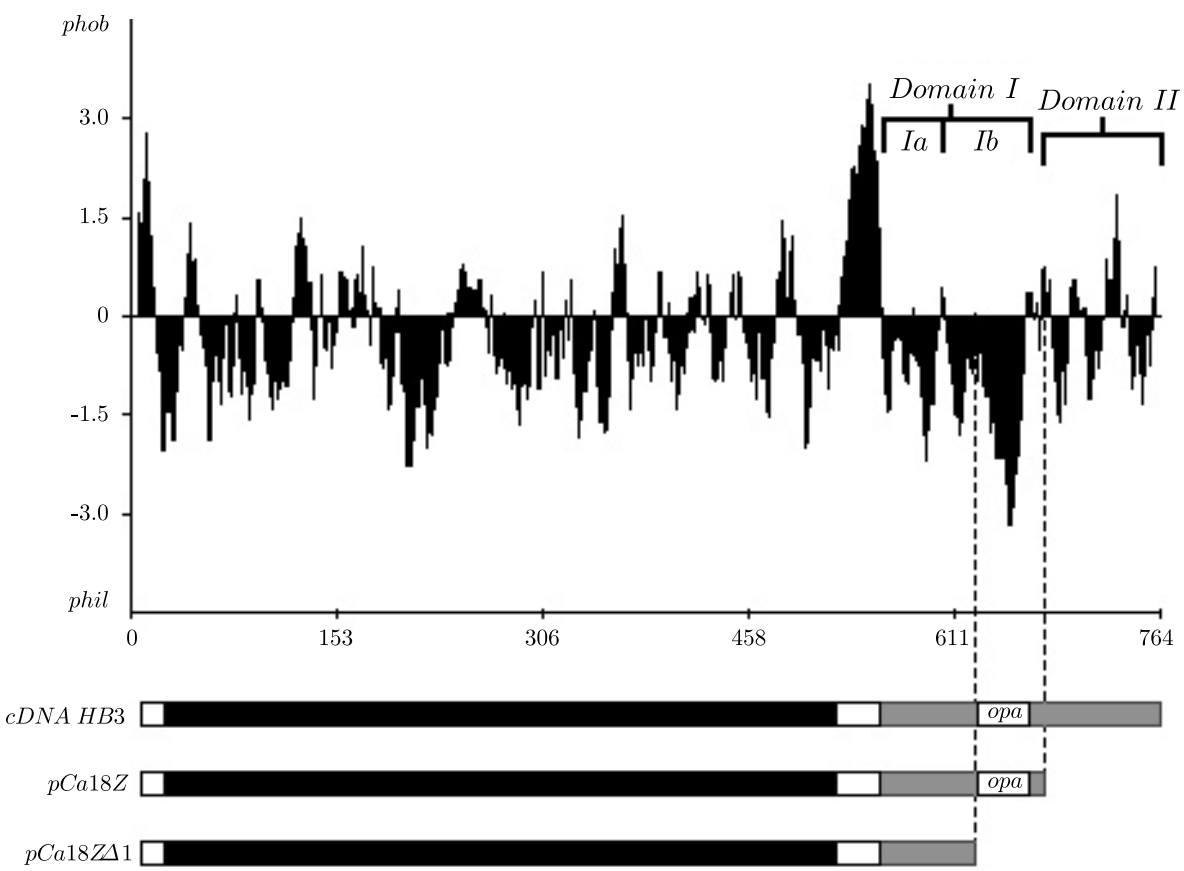

Fig. 1 - Structural organization of the complete Rst-IrreC protein and the truncated forms produced by the constructs tested in this work. A hydropathic profile of the Rst-IrreC protein is shown in the upper part of the figure. The intracellular subdomains and the opa region are indicated (see text for details). In the lower part, the boxes indicate how much of the wild type protein remains in the truncated products. White, signal peptide and transmembraned domains. Gray, intracellular domain: the approximate location of the opa-like sequence is shown. Black, extracellular domain.

individuals. Here we showed that transient expression of a truncated version of the rst-irreC cDNA encoding a protein lacking the last 80 amino acids present in the carboxyl terminus of the wild type molecule lead to a dramatic decrease in post embryonic viability compared to controls injected either with the vector alone or with a construct encoding the complete wild type protein. Removal of 140 additional nucleotides encoding a region unusually rich in glutamine restores the survival rates to levels comparable to the ones observed when the wildtype cDNA was injected.

Longer than normal glutamine tracts in the coding region of specific genes have been found consistently associated with a number of important human neurodegenerative disorders and are directly responsible for at least two of them, Huntington disease (Mangiarini et al. 1996) and Machado Joseph
Disease (Ikeda et al. 1996). The pathogenic effect of these expanded glutamine repeats is independent of the polypeptide in which it is present since the "in vitro" insertion of CAG repeats in nondisease protein can also induce neurodegeneration “in vivo" (Ordway et al. 1997). Also, the susceptibility of Drosophila to glutamine repeat disease has been demonstrated, very elegantly, by two studies: in one of them (Warrick et al. 1998) the expression, in the compound eye, of the carboxy-terminal fragment of ataxin-3 containing 27 glutamines (the wildtype number) plus the 43 downstream amino acids does not seem to cause any deleterious effect, while the expression of the same construct but with a 78 amino acid long expanded glutamine repeat present in patients with Machado-Joseph Disease shows late-onset progressive cell degeneration, with neurons being particularly sensitive. The cell 


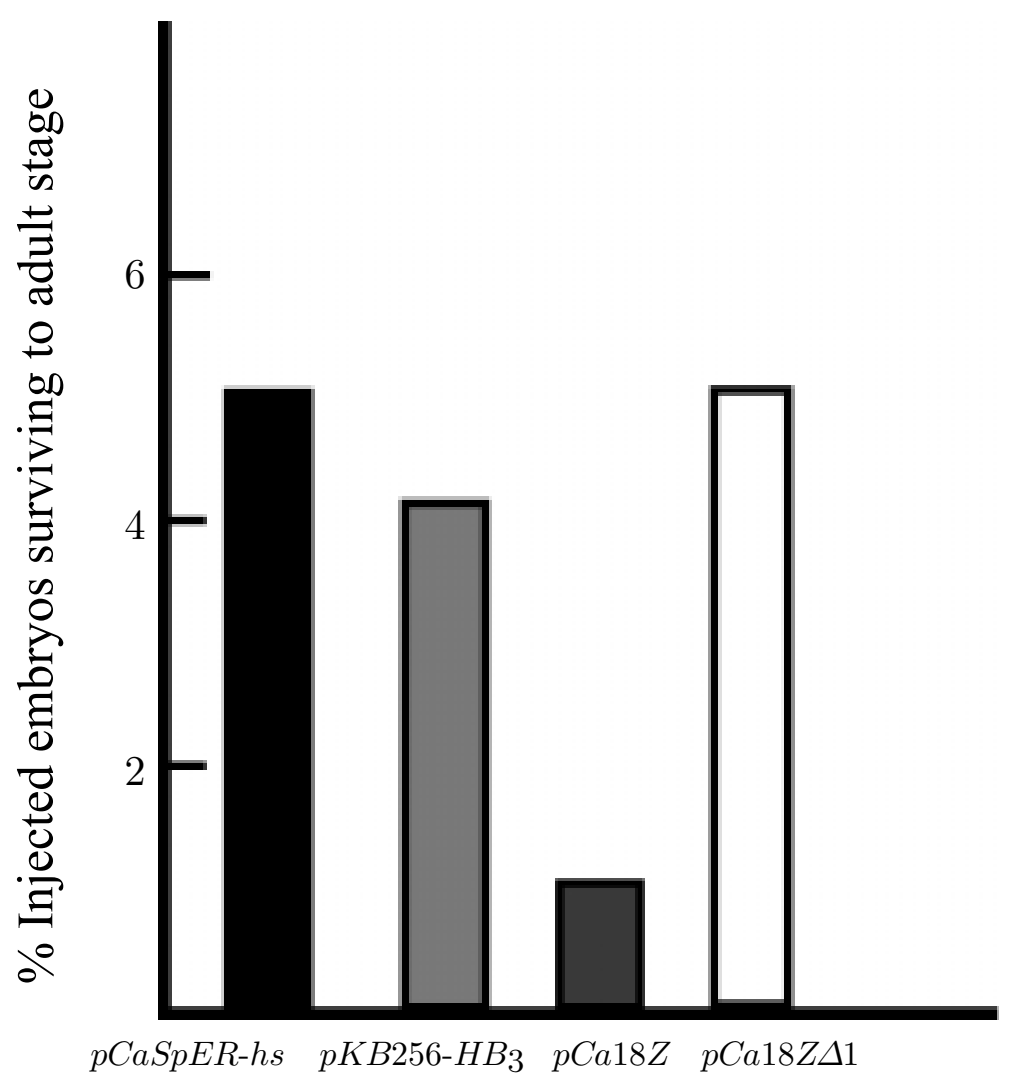

Fig. 2 - Percentage of embryos surviving to adulthood after having been injected, before cellularization, with plasmids carrying two different $r s t$-irre C constructs (pCa18Z, pCa18Z $\Delta 1$ ) or with a control plasmid (pCaSpER-hs). A clear reduction in adult survivors is observed in the group of embryos injected with construct pCa18Z. Total number of injected individuals: pCa18Z, 2027; pCa18Z 1 1, 1019; pCaSpER-hs, 836; pKB256-HB3 356.

degeneration could be partially suppressed by the antiapoptotic protein $\mathrm{p} 35$. Similar results were observed with the expanded repeats present in Huntingtin (Jackson et al. 1998), although in this case the apoptotic nature of the cell degeneration remains unclear. Interestingly, expression of mutant ataxin 3 earlier in development, in presumptive mesoderm and muscle cells results primarily in larval lethality (Warrick et al. 1998). In our study it was the removal of sequences downstream to the glutaminerich region, rather than its expansion, that caused the observed decrease in post embryonic viability. Besides, although the 47 amino acid sequence of
Rst-IrreC whose presence seems to be necessary to induce the toxic effect contains 13 glutamines clustered around a $23 \mathrm{aa}$ long stretch, the longest continuous glutamine repeat present is only 6 amino acids long, clearly much smaller than the minimal number of 35-40 residues reported to cause disease. This raises the question of whether the $\mathrm{pCa} 18 \mathrm{Z}$ toxic effect has the same pathogenic causes of the aforementioned diseases, or it is a consequence of a completely different mechanism. A characteristic pathological feature, present in all glutamine repeat diseases reported so far is the aggregation, in the nucleus, of the expanded polyglutamine tracts present 


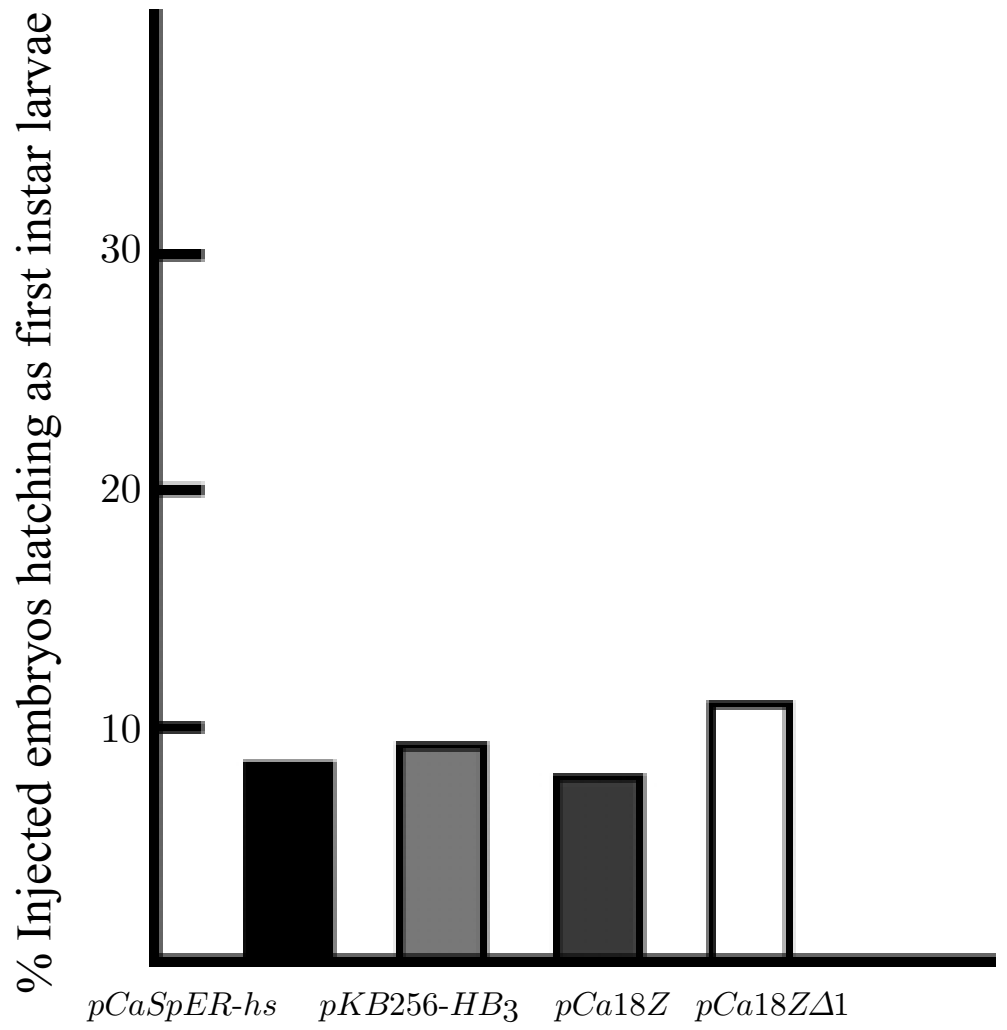

Fig. 3 - Percentage of larvae hatching from embryos injected before cellularization with plasmids carrying the same rst-irre C constructs and control as in figure 2 . No obvious survival differences could be detected between the injected DNAs.

in the mutant proteins which became enclosed by a single amorphous intranuclear inclusion, although this seems to be a protection mechanism rather than a trigger for the apoptotic neuronal degeneration responsible for the onset of the disease (Klement et al. 1998, Saudou et al. 1998). Their presence in larvae of embryos injected with pCa18Z would strongly argue for a common pathogenic mechanism between glutamine repeat disease and the post embryonic lethality associated to $\mathrm{pCa} 18 \mathrm{Z}$ described here.

Another important point raised by our results is their significance for $r s t$-irre $C$ wild type function. In principle, the decrease in viability caused by the pCa18Z construct could be simply a consequence of an accidental "gain of toxic function", bearing no relationship whatsoever to Rst-irreC physiological role. On the other hand, the absence of the last
174 amino acids of the Rst-irreC carboxyl terminus, which includes the glutamine-rich domain, is sufficient to prevent apoptotic elimination of surplus interommatidial cells in the final steps of ommatidial development (Ramos et al. 1993), showing that these sequences are critical for rst-irreC function in the compound eye. The exact nature of the involvement of the Rst-irreC protein with programmed cell death in ommatidial pattern formation remains unclear and it was suggested (Reiter et al. 1996) that Rst-irreC could be primarily required for interomatidial cell sorting, this process being a pre requisite for the activation of the apoptotic program in the appropriate cells. Recent results, however, indicate that rst-irreC may trigger programmed cell death of surplus interommatidial cells independently of their reorganization (Miller and Cagan 1998). Our obser- 


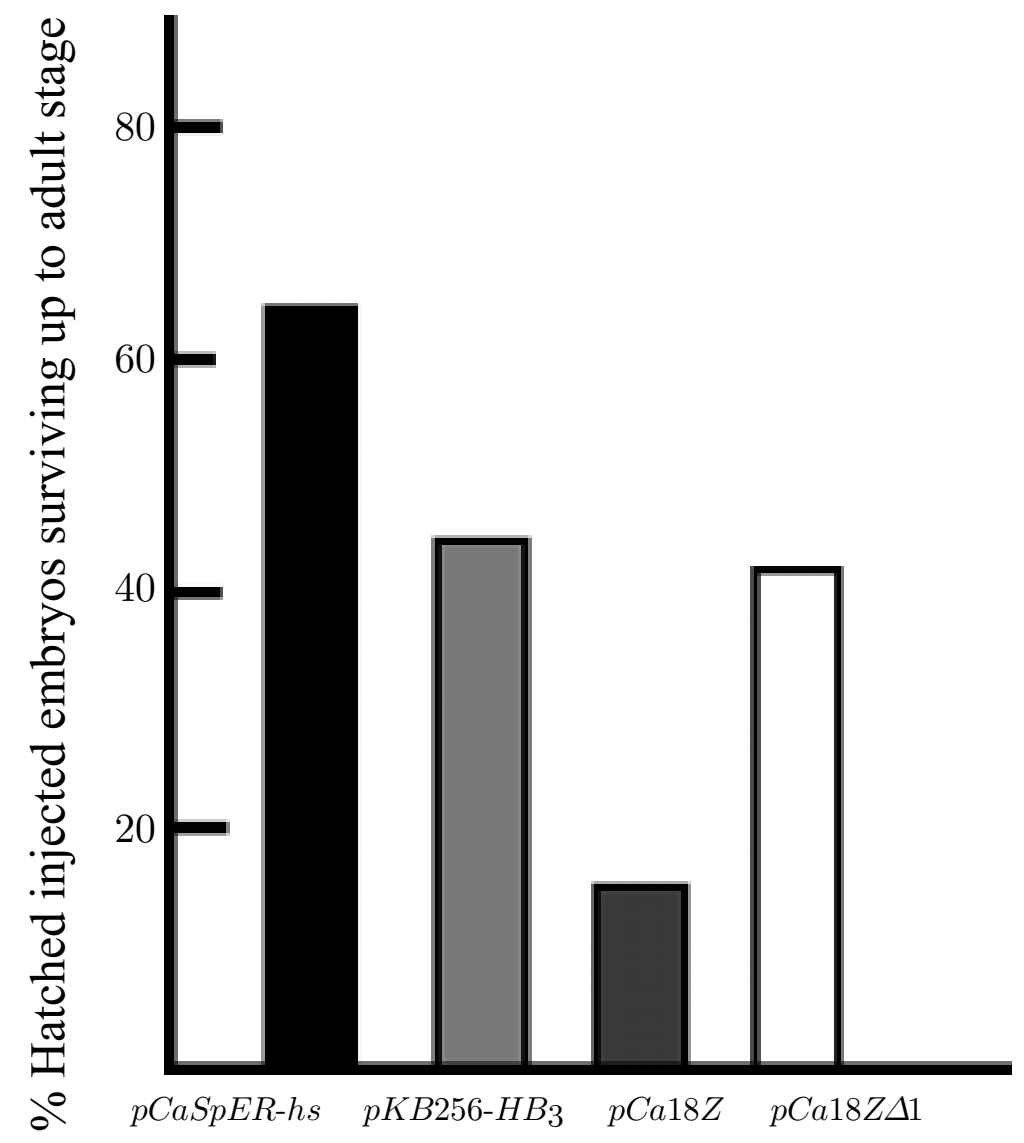

Fig. 4 - Percentage of adults eclosed from the surviving larvae obtained in the experiment shown in figure 3. The individuals injected with pCa18Z showed the lowest eclosion rate, but the other two rst-irre $C$ constructs, pCa18Z $\Delta 1$ and pKB256-HB3 also seem to be able to decrease post embryonic viability, although not as severely as pCa18Z.

vations could be explained by a model in which the carboxyl terminus of the Rst-irreC molecule inhibits a "death inducing" activity of the glutamine-rich domain. Conformational changes resulting from the activation of the molecule (consequence of binding to an extracellular ligand, for example) could remove this inhibitory effect, resulting in a toxic effect leading to apoptosis. The sequence deleted in pCa18Z contain motifs such as putative tyrosine phosphorylation sites and the PDZ domain recognition sequence potentially capable of either bring about conformational changes or to stabilize those induced in the intracellular domain from the outside.
Additionally, some glutamine-rich domains seem to be able to directly activate transcription, (Courey and Tjian 1988, Courey et al. 1989) although in this case the question of how would the appropriate Rst-irreC sequences be translocated to the nucleus remains completely open.

Finally it is important to stress that, although compelling, the results reported in this study must be interpreted with caution, due to the intrinsic limitations of the transient assay methodology. For instance, the rate of protein translation may differ for the different constructs, or their RNA stability may be different. Both these circumstances could, 
in principle, affect the survival rate of the injected individuals, leading to a false conclusion regarding the molecular basis of the observed toxicity. Further testing of these and the above mentioned hypothesis, together with a detailed investigation of the cellular basis of the toxic effect reported here will require the generation of germline transformed flies carrying $\mathrm{pCa} 18 \mathrm{Z}$ and $\mathrm{pCa} 18 \mathrm{Z} \Delta 1$, as well as other constructs specifically disrupting the carboxyl terminal motifs mentioned above. Such experiments are currently under way.

\section{ACKNOWLEDGMENTS}

We thank Dr. K-F Fischbach for plasmid pKB 256HB3 and Dr. M. Marins for help with some of the constructs and their sequencing. Special thanks go to Dr. E. Abdelhay in whose laboratory, at the Institute of Biophysics "Carlos Chagas Filho" of the Federal University of Rio de Janeiro, some of the initial work described in this paper was performed. This research was supported by grants from Third World Academy of Science, CNPq (\#523298/94-3) and FAPESP (\#96/6235-2; 00/07478-3).

\section{RESUMO}

O gene roughest-irregular chiasm C (rst-irreC) de Drosophila melanogaster, codifica uma glicoproteína transmembranar contendo cinco domínios semelhantes a imunoglobulina em sua porção extracelular e uma cauda intracitoplasmática rica em serina e treonina, assim como alguns sequências conservadas que sugerem atividade transdutora de sinais. No olho composto, mutantes rst-irreC de perda de função não apresentam uma característica " onda" de morte celular programada que ocorre no início do período pupal e que é essencial para a eliminação de células interomatidiais em excesso. Aqui descrevemos uma investigação sobre o papel desempenhado pela molécula Rst-IrreC no disparo da morte celular programada. Ensaios de expressão transiente "in vivo" demonstraram que a remoção dos 80 aminoácidos finais da porção carboxil terminal produz uma isoforma da proteína que é extremamente tóxica para as larvas. Esta toxicidade é suprimida se 47 aminoácidos adicionais, contendo uma região rica em glutamina (região “opa-like"), forem também removidos da proteína. Os resultados sugerem a possibilidade de que o domínio "opa-like" e o terminal carboxila ajam em conjunto para modular a função de rst-irreC na apoptose, e esta implicação é discutida dentro do contexto dos mecanismos gerais causadores de doenças neurodegenerativas associados a proteínas ricas em glutamina em humanos.

Palavras-chave: Drosophila, rst-irreC, regiões ricas em glutamina, morte celular.

\section{REFERENCES}

Ashburner M. 1989. Drosophila. A laboratory manual. Cold Spring Harbor Laboratory Press, Cold Spring Harbor, NY. p. 402.

Ashrenazi A ANd Dixit VM. 1998. Death receptors: signaling and modulation. Science 281: 1305-1308.

Boschert U, Ramos RGP, Tix S, Technau G and FisСнвACH K-F. 1990. Genetic and developmental analysis of irreC, a genetic function required for optic chiasm formation in Drosophila. J Neurogenet 6: 153-171.

Courey AJ And Tuian R. 1988. Analysis of $\mathrm{Sp} 1$ in vivo reveals multiple transcription domains, including a novel glutamine-rich activation motif. Cell 55: 887898.

Courey AJ, Holtzman DA, Jackson SP and Tuian R. 1989. Synergistic activation by the glutamine-rich domains of human transcription factor Sp1. Cell 59: 827-836.

Green DR and Reed JC. 1998. Mitochondria and apoptosis. Science 281: 1309-1312.

Gusella JF, McNeil S, Persichetti F, SRinidhi J, Novelleto A, Bird E, Faber P, Vonsattel J-P, Myers R And MacDonald ME. 1996. Huntington's Disease. Cold Spring Harbor Symp. Quant Biol 61: 615-626.

Ikeda H, Yamaguchi M, Sugai S, Aze Y, Narumiya S AND KaKIzUKa A. 1996. Expanded polyglutamine in Machado-Joseph disease protein induces cell death "in vitro and "in vivo". Nature Genet 13: 196-202.

Jackson GR, Salecker I, Dong X, Yao X, Arnheim N, Faber PW, MacDonald ME and Zipursky SL. 1998. Polyglutamine-expanded human Huntingtin transgenes induce degeneration of Drosophila photoreceptor neurons. Neuron 21: 633-642. 
Kawaguchi Y, OKamoto T, Taniwaki M, Aizawa M, InOUe M, Katayama S, KaWaKami H, NaKamura S, Nishimura M, AKiguchi I, Kimura J, NarumiYa S AND KaKizUKa A. 1994. CAG expansions in a novel gene for Machado-Joseph disease at chromosome 14q32.1. Nature Genet 13: 221-228.

Klement IA, Skinner PJ, Kaytor MD, Yi H, Hersch SM, Clark HB, Zoghbi HY and OrR HT. 1998. Ataxin-1 nuclear localization and aggregation: Role in polyglutamine-induced Disease in SCA1 transgenic mice. Cell 95: 41-53.

Koide R, Ikeuchi T, Onodera O, Tanaka $\mathrm{H}$, Igarashi S, Endo K, Takahashi H, Kondo $\mathrm{R}$, Ishikawa A, Hayashi T, Saito M, Tomoda A, Mirke T, Naito H, Ikuta F and Tsuji S. 1994. Unstable expansion of CAG repeat in hereditary dentatorubral-pallidoluysian atrophy (DRPLA). Nature Genet 13: 9-13.

La Spada AR, Wilson EM, Lubahn DB, Harding AE AND FischBECK KH. 1991. Androgen receptor gene mutations in X-linked spinal and bulbar muscular atrophy. Nature 352: 77-79.

LindsLey D AND Zimm GG. 1992. The genome of Drosophila melanogaster. 2nd edn. Academic Press, San Diego, CA.

Lis JT, Simon JA And Sutton CA. 1983. New heat shock puffs and Beta Galactosidase activity resulting from transformation of Drosophila with an hsp70lacZ hybrid gene. Cell 35: 403-410.

Machado RC. 1997. Análise funcional “in vivo" do locus rst-irreC de Drosophila melanogaster. MSc dissertation, Federal University of Rio de Janeiro. pp 71-72.

Mangiarini L, Sathasivam K, Seller M, Cozens B, Harper A, Hetherington C, Lawton M, Trottier Y, Lehrach H, Davies SW and Bates GP. 1996. Exon 1 of the gene with an expanded CAG repeat is sufficient to cause a progressive neurological phenotype in transgenic mice. Cell 87: 493-506.

Martin P, Martin A, Osmani A and Sofer W. 1986. A transient expression assay for tissue especific gene expression of alcohol dehydrogenase in Drosophila. Dev Biol 117: 574-580.

Miller DT and Cagan RL. 1998. Local induction of patterning and programmed cell death in the developing retina. Development 125: 2327-2335.
Nagafuchi S, Yanagisawa H, Sato K, Shirayama T, OHsaki E, Bundo M, Takeda T, Tadokoro K, Kondo I, Murayama Net al. 1994. Dentato rubral and pallidoluysian atrophy expansion of an unstable CAG trinucleotide on chromosome 12p. Nature Genet 6: 14-18.

Ordway JM, Tallaksen-Greene S, Gutekunst C-A, Bernstein EM, Cearley JA, Wiener HW, Dure IV SL, Lindley R, Hersch SM, Jope RS, Albin RL AND Detloff PJ. 1997. Ectopically expressed CAG repeats cause intranuclear inclusions and a progressive late onset neurological phenotype in the mouse. Cell 91: 753-763.

Ponting CP, Phillips C, Davies KE and Blake DJ. 1997. PDZ domains: targeting signalling molecules to submembranous sites. BioEssays 19: 469-479.

RAFF M. 1998. Cell suicide for beginners. Nature 396: 119-122.

Ramos RGP. 1988. Análise funcional do locus Notch de D. melanogaster através de transformação mediada por elementos P. PhD Thesis, Federal University of Rio de Janeiro.

Ramos RGP, Igloi GL, Baumann U, Maier D, Lichte B, Schneider T, Brandstätter JH, Fröhlich A AND FischBACH K-F. 1993. The irregular chiasm Croughest locus of Drosophila which affects axonal projections and programmed cell death encodes a novel immunoglobulin-like protein. Genes Dev 7: 2533-2547.

Reiter C, Schimansky T, Nie Z and Fischbach K-F. 1996. Reorganization of membrane contacts prior to apoptosis in the Drosophila retina: the role of IrreCrst protein. Development 122: 1931-1940.

Sambrook J, Fritsch EF and Maniatis T. 1989. Molecular cloning. A laboratory manual. 2nd edn. Cold Spring Harbor laboratory Press, Cold Spring Harbor, NY.

Saudou F, Finkbeiner S, Devys D and Greenberg ME. 1998. Huntingtin acts in the nucleus to induce apoptosis but death does not correlate with the formation of intranuclear inclusions. Cell 95: 55-66.

Schneider T, Reiter C, Eule E, Bader B, Lichte B, Nie Z, Schimansky T, Ramos RGP ANd FischbaCH K-F. 1995. Restricted expression of the IrreC-Rst protein is required for normal axonal projections of columnar visual neurons. Neuron 15: 259-271. 
SPRADLING AC. 1986. P-element mediated transformation. In: Drosophila, a practical approach, (Roberts BD, ed.), IRL Press, Oxford. pp. 175-197.

Steller H and Pirrota V. 1984. Regulated expression of genes injected into early Drosophila embryos. EMBO J 3: 165-173.

Steller H and Pirrota V. 1985. Fate of DNA injected into early Drosophila embryos. Dev Biol 109: 54-62.

Strünkelnberg M, BONengel B, Moda LMR, Hertenstein A, De Couet HG, Ramos RGP and FISCHBACH K-F. 2001. $r s t$ and its paralogue kirre act redundantly during embryonic muscle development in Drosophila. Development 128: 4229-4239.

Thornberry NA AND LaZebnick Y. 1998. Caspases: Enemies within. Science 281: 1312-1316.

Thummel CS and Pirrota V. 1991. New pCasper Pelement vectors. Dros Inf Service 71: 150.
Warrick JM, Paulson hL, Gray-Board GL, Bui QT, Fischbeck KH, Pittman RN and Bonini NM. 1998. Expanded polyglutamine protein forms nuclear inclusions and causes neural degeneration in Drosophila. Cell 93: 939-949.

Wharton KA, Yedvobnick B, Finnerty VG and Artavanis-Tsakonas S. 1985. Opa: a novel family of transcribed repeats shared by the Notch locus and other developmentally regulated loci in $D$. melanogaster. Cell 40: 55-62.

WolfF T And Ready D. 1991. Cell death in normal and rough eye mutants of Drosophila. Development 113: 825-839.

WolfF T and Ready D. 1993. Pattern Formation in the Drosophila Retina. In: The Development of Drosophila melanogaster (Bate, M. and Martinez Arias, A., eds) Cold Spring Harbor Laboratory Press, Cold Spring Harbor, NY, pp 1277-1325. 